胆管狭窄を伴う慢性膵炎症例

一臨床像执よび術式の検討一

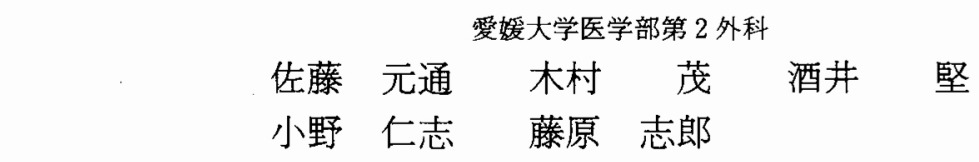

\title{
CHRONIC PANCREATITIS WITH COMMON BILE DUCT STRICTURE -STUDIES ON CLINICAL FINDINGS AND OPERATIVE PROCEDURES-
}

\author{
Motomichi SATO, Shigeru KIMURA, Ken SAKAI, \\ Hitoshi ONO and Shiro FUJIWARA
}

The Second Department of Surgery, Ehime University School of Medicine

\begin{abstract}
胆管狭窄をともなら慢性苏炎 6 例を検討した。
1）黄㡺は 4 例でみられ，5ち 3 例は自然消退したが，1例は胆管完全閉塞に対し経皮的胆管ドレ ナージを要した，2）胆管炎・胆囊炎は 5 例, 胆石は 3 例に認められ，胆汁細菌培養は60\%で陽性であっ た. 3）胆管像は全例で総胆管拡張をともない, 䐙内胆管しめつけ 2 例，不整狭窄 2 例，压排 1 例，完 全閉塞 1 例が認められた，4）胆道・膵同時バイパス 4 例（Double Roux-Y 2, $\rho$ loop, Roux-Y 1, 胆管 十二指腸吻合兼囊胞空腸吻合 1 例), 胆管十二指腸吻合 1 例 (空腸間置法), 膵十二指腸切除 1 例を行 い良好な成績を得た。以上より胆管狭窄をとるなった慢性脇炎は胆汁らっ滞・胆道系炎症を高率に合 併するため，症例に応じた適切な胆道再建術を要するものと考えられた。
\end{abstract}

索引用語：慢性脇炎と胆管狭窄, 慢性荤炎と胆道再建, 慢性荤炎と胆道感染

\section{I.はじめに}

慢性膵炎では種々の合併症をともならが, 胆道系病 変, とくに胆管狭窄は, 最近の診断技術の向上に上り 次第にその実態が明らかとなってきだ位。しかしな がら，胆管狭窄に対しては手術を要するといら意

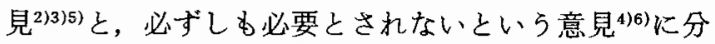
かれ，手術適応に関して統一的な見解が得られていな い.また手術術式もさまざあな方法があり ${ }^{1224) 77}$, 胆道 バイパス術式を行らとしても，莝管ドレナージとあわ せて行うことが多いため, バイパス経路が問題となる.

私たちは 6 例の胆管狭窄をともなった慢性脺炎症例 に対し，腪直接手術とともに胆道バイパス手術を施行 したので, その臨床像, 術式, 治療成績とともに, 慢 性脞炎に持ける胆管狭窄合併の病態を検討した。

$<1984$ 年 9 月 19 日受理 >別刷請求先：佐藤 元通 T791-02 愛媛県温泉郡重信町志津川29，愛媛大学医 学部第 2 外科

\section{II. 対象および方法}

1）対象症例（表 1）:1979年 1 月から1984年 2 月ま でに愛媛大学第 2 外科に入院し, 手術が施行された慢 性腪炎で, 胆管造影にて膵内胆管の狭窄像がみられた 6 例を対象とした。慢性莝炎は日本消化器病学会の基 準8)により診断された。症例は 45 歳 66 歳, 平均 55 歳, 男 5 例, 女 1 例であった。成因は女性例が胆石性であっ た以外は, アルュール性であった。全例が合併症を有 して和り, 糖尿病 4 例（インスリン療法 3 , 経口糖尿 病薬服用 1 例), 脞囊胞 3 例 (頭部 2 , 尾部 1 例), 膵 石 3 例, 胆霊・胆管炎 5 例, 胆石 3 例（泥状 - 軟 - 小 の少数個の胆雴内ビ系石 2 例, 多数の硬い総胆管 - 胆 囊内ど系石 1 例), 胃實瘍 1 例がみられた。 そのほかで は, 胃癌が 2 例にみられた（胃癌術後 5 年経過 1 例, 胃癌と同時手術 1 例).

2) 手術術式(表 1，3, 図 1)：胆管狭窄に対して積 極的に胆道バイパス術を付加し，荤管拡張例に対して は可及的に脇を温存し，腪管空腸側々吻合 (Partington 
表 1 対象

\begin{tabular}{|c|c|c|c|c|c|}
\hline No. & 年齢・性 & 成 因 & 合 併 症 & 式 & 転 \\
\hline 1 & $53 \cdot$ 男 & アルコール & $\begin{array}{l}\text { 糖尿病, 胃潰瘍 } \\
\text { 胆管炎 }\end{array}$ & $\begin{array}{l}\text { 苹管·空腸側々吻合, 胆摘 } \\
\text { 胆管・空腸吻合 (double Roux-Y) }\end{array}$ & 1 年 3 月生・良好 \\
\hline 2 & $45 \cdot$ 男 & アルコール & $\begin{array}{l}\text { 腪頭部囊胞, 㬸石 } \\
\text { 胆石・胆裹炎, 糖底病 }\end{array}$ & 胆管·空腸吻合 (double Roux-Y) & 生・良好 \\
\hline 3 & $57 \cdot$ 男 & フルコール & 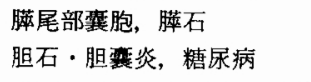 & $\begin{array}{l}\text { 膵管・胆管・空腸吻合 }(\rho \text { loop Roux-Y) } \\
\text { 胆摘, 摘脾 }\end{array}$ & 1 年 8 月生・良好 \\
\hline 4 & $66 \cdot$ 女 & 胆 石 & $\begin{array}{l}\text { 脞頭部囊胞, 十二指腸狭窄 } \\
\text { 胆石, 胆䨟炎 }\end{array}$ & $\begin{array}{l}\text { 胃㚬，蚝胞・空腸吻合，胆摘 } \\
\text { 胆管・十二指腸吻合 }\end{array}$ & 4 年10月生・良好 \\
\hline 5 & $58 \cdot$ 男 & アルュール & $\begin{array}{l}\text { 腪頭部腫瘤，胆囊炎 } \\
\text { 胃癌手術暦 }\end{array}$ & 荤頭十二指腸切除 (Child) & 2 年 6 月生・良好 \\
\hline 6 & $51 \cdot$ 男 & アルコール & 糖屟病, 胃癌, 脞石 & $\begin{array}{l}\text { 胃亜全摘 (BI), 胆摘 } \\
\text { 胆管・十二指腸吻合 (有茎空腸間置) }\end{array}$ & 1 月生・良好 \\
\hline
\end{tabular}

1979. $1-1984.3$ 愛媛大 2 外科

\section{表 2 臨床症状, 検查成績}

\begin{tabular}{|c|c|c|c|c|c|c|c|}
\hline \multirow{2}{*}{ No. } & \multirow{2}{*}{ 黄疸既往 } & \multirow{2}{*}{ 臨床症状 } & \multicolumn{5}{|c|}{ 入院時検査成績 } \\
\hline & & & T. Bil & ALP & $\gamma \mathrm{GTP}$ & PFD & 血アミラーゼ \\
\hline 1. & + (1 回, 消失) & $\begin{array}{l}\text { 左右季助部痛, 発熱, } \\
\text { るいそう }\end{array}$ & 0.9 & 129 & 142 & 59.4 & 123 \\
\hline 2 . & $+(1$ 回, 増悪 $)$ & $\begin{array}{l}\text { 腰背部·右季助部痛, } \\
\text { 心窩部不快感 }\end{array}$ & 9.4 & 1092 & 132 & 33.9 & 46 \\
\hline 3. & - & $\begin{array}{l}\text { 脐上部痛，口渴，るい } \\
\text { そう }\end{array}$ & 0.6 & 204 & 90 & 29.0 & 221 \\
\hline 4. & + (2 回, 消失, 不変) & $\begin{array}{l}\text { 食思不振, 全身倦意, } \\
\text { 右季助部痛, 発熱 }\end{array}$ & 1.6 & 1660 & 727 & - & 208 \\
\hline 5 . & + (1 回, 消失) & $\begin{array}{l}\text { 発熱, 体重減少, 上腹 } \\
\text { 部痛 }\end{array}$ & 0.9 & 141 & 62 & 42.4 & 92 \\
\hline 6. & - & るいそう，口渴 & 0.6 & 192 & 15 & - & 86 \\
\hline
\end{tabular}

※正常値: T. Bil (血清総ビリルビン) : 0.1〜0.6mg/dl

ALP (血清アルカリフォスファターゼ) : 57〜144 IU/1

rGTP（血清 $\gamma$ グルタミルトランスペプチターゼ）：0〜31 IU/1

PFDテスト：70\%以上

血清アミラーゼ : $61 〜 202$ Somogy

表 3 胆管像・膵管像, 門脈一脾静脈像

\begin{tabular}{|c|c|c|c|c|}
\hline No. & 满 石 & 膵内胆管像 & 苹 管 像 & 門脈一脾静脈像 \\
\hline 1. & $(-)$ & 管状しめつけ & びまん払張 & 脾静脈閉塞 \\
\hline 2 . & $(+)$ & 完全閉塞・圧排 & びまん性拡張 & - \\
\hline 3 . & $(+)$ & 不整狭窄 & びまん性抎張 & 門脈狭窄, 脾静脈閉塞 \\
\hline 4. & $(-)$ & 正排 & 頭部拡張, 中断 & 正常 \\
\hline 5 . & $(-)$ & 管状しめつけ & 中断, 拡張なし & 門脈狭窄, 脾静脈閉塞 \\
\hline 6 . & $(+)$ & 不整狭窄 & 执張なし & 正常 \\
\hline
\end{tabular}

手術9)を原則として行った。 また胆道バイパス術は胆 摘を行い, 胆道本管と消化管を吻合している. しかし, 術前, 術中精査, 特有の合併症を考慮し, 個々の症例 に適した術式を選択したため, 術式に若干差が生じた。
術式としては，膵管びまん払張例（症例 $1,2,3$ ）に は，膵管・空腸吻合兼胆管・空腸吻合を double RouxY で再建する術式（double Roux-Y） 2 例， ploop K よる一期的膵管・胆管・空腸吻合を Roux-Y で再建す 
図 1 胆管, 荤管バイパス術式

\section{勧営・罙腸側又吻合 \\ 胆管 · 空膆汤合}

(double Roux-Y)

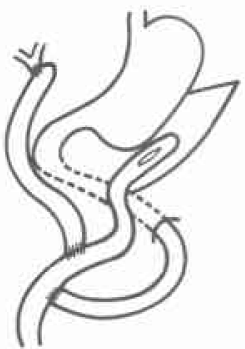

症例 1,2

昂切, 覃胞・空晹吻合

胆管·十二指腸吻合

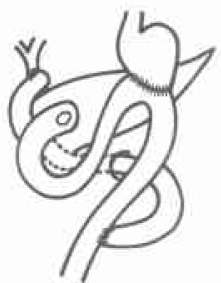

症例 4

\section{席管・胆管・空得旸合}

( $\rho$ loop RouX-Y)

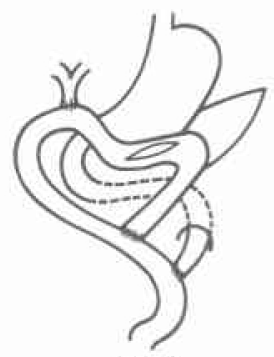

在陵了

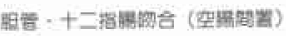
需切

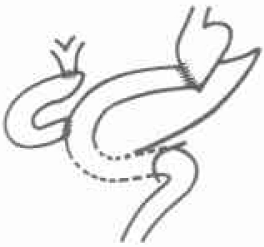

些的 6

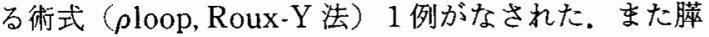
頭部壊胞と十二指腸狭窄が認められた症例 4 Kは, 胃 切, 囊胞・空腸吻合兼胆管・十二指腸吻合がなされた。 さらに膵頭部腫瘤を形成し癌が強く疑われた症例 5 に は㬸頭十二指腸切除を行った。な括疼痛・膵管拡張は ともなわなかったが，胃癌が併存した症例 6 には，胃 亜全摘，有茎空腸間置法による胆管十二指腸吻合）が 施行された。

3）検討方法：上記の 6 例につき, 臨床症状, 検查所 見, 胆管像, 膵管像, 門脈・脾静脈像, 胆汁細菌培養, 胆囊の組織像などを検討し，手術成績と対比した。

III. 結 果 (表 2,3)

1）臨床症状：黄㾝の既往は 4 例 $(67 \%)$, 延べ 5 回 認められた。 がピーク時 $15.0,6.9 \mathrm{mg} / \mathrm{dl}$ まで上昇したが 30 日，15日 で黄疸は自然消退して, 入院時は認められなかった。 総胆管結石をともなった症例 4 では，ピーク時総ビリ ルビンが $2.6 \mathrm{mg} / \mathrm{dl}$ まで上昇する発作が 1 度出現し 1 カ月で消失した後, 7 力月後に再び軽度の黄疸ば現れ た。一方胆管の完全閉塞状態となった症例 2 では最高 $25.0 \mathrm{mg} / \mathrm{dl}$ に上昇し, 経皮経肝胆管ドレナージ (PTCD)によるドレナージを手術直前をで要した。そ

図 2 症例 2,4 の胆管像

症例 2 : 膵内胆管の完全閉塞と胆管拡張像

症例 4 ：下部胆管の王排・狭乍・結石陰影々胆管抎張像

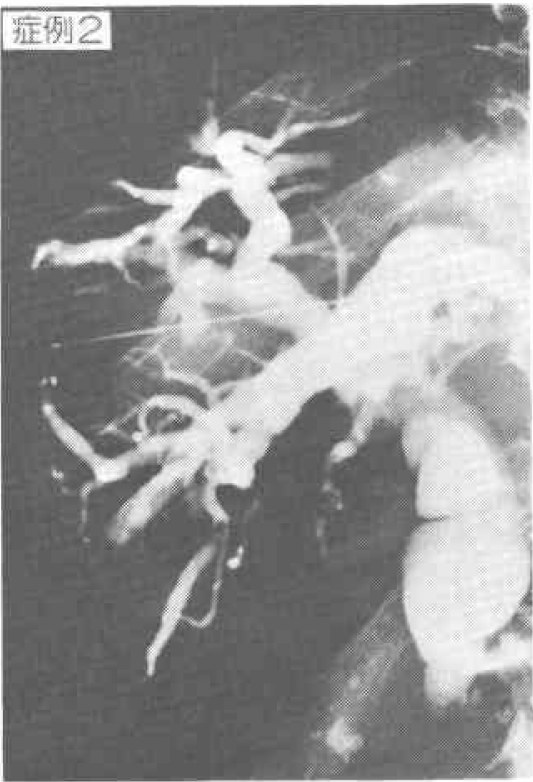

胆管閉塞

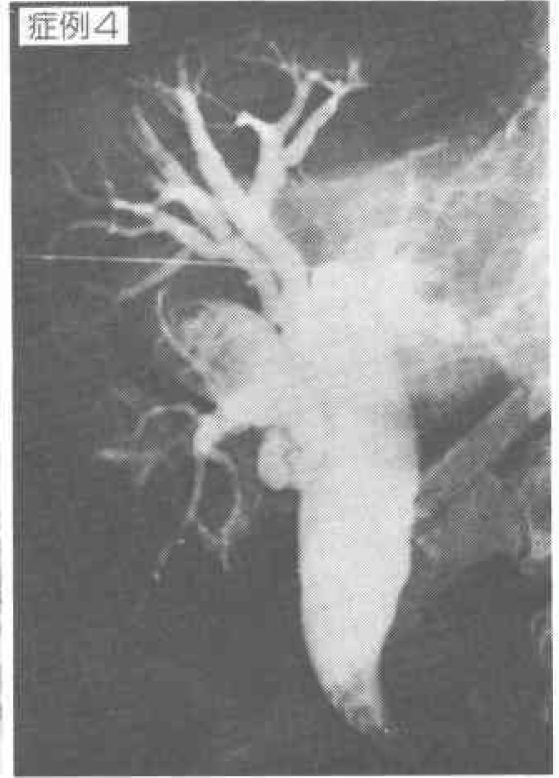

胆管圧排・胆石 
図 3 症例 3 の胆管像, 門脈像

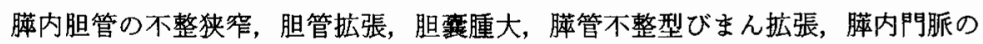
不整狭窄・しめつけ, 脾静脈の閉塞像

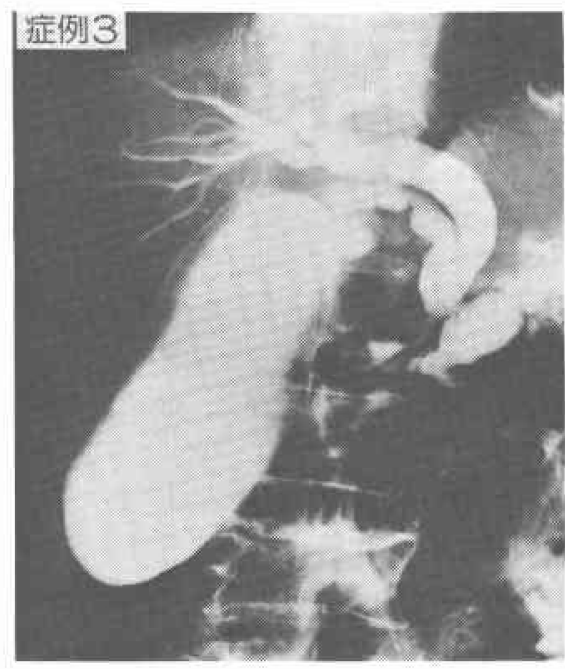

胆管不整狭窟

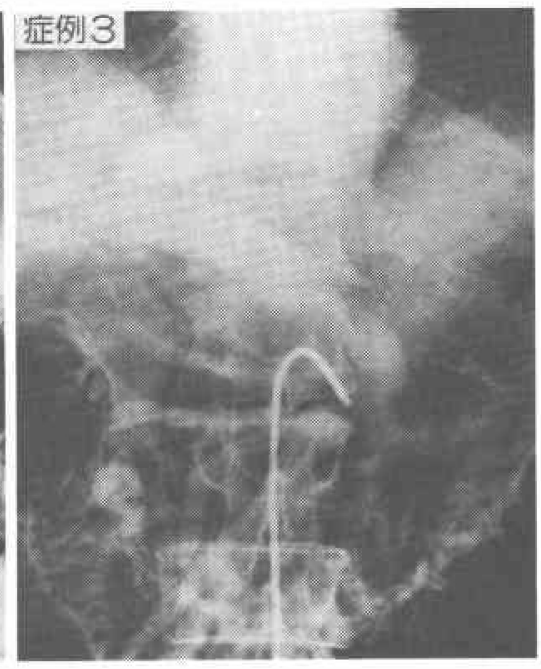

門脈狭窄・脾静脈閉塞
のほかでは胆管炎を思わせる発熱が 3 例, 疼痛 5 例, るいそら・体重減少 4 例, 口渴感 2 例が認められた。 病悩期間は 1 年〜 18 年, 平均 7 年間であった。

2）入院時検查成績：入院時血清総ビリルビン（T. Bil) は症例 2 で高値, 症例 4 で軽度上昇がみられた以 外は正常域内であった。一方血清アルカリフォスファ ターゼ (ALP), 血清 $\gamma$ グルタミルトランスペプチター ゼ（ $\gamma$-GTP）はそれぞれ 4 例，5例で高值をとった。 また脞機能ではPancreatic Function Diagnostant (PFD)テストが施行 4 例で全例異常低值をとり，血清 アミラーゼは 1 例で軽度高值を示した以外は注ぼ正常 範囲内であった。

3）胆管像（表 3, 図 2,3）：佐藤らの分類 ${ }^{4} に$ 従い 記載すると, 管状しめつけ像 2 例, 不整狭窄像 2 例, 王排像 2 例, 完全閉塞像 1 例が認められた。 また膵石 を有する例では，不整狭窄 2 例，完全閉塞 1 例が認め られ，やや狭窄の程度が強いように思われた。なお压 排像がみられた 2 例は膵頭部囊胞合併例であった。さ らに肝側の総胆管の拡張像は全例で認められた。

症例中 3 例で 2 回以上, 数力月の間隔で胆道造影が 追跡された，症例 1 では 6 カ月前にも胆道造影が行わ れていたが，入院時は以前より胆管狭窄の程度がやや 強くなっていた。症例 2 では43日間 PTCD ドレナージ がなされこの間には胆道造影が繰り返し行われたが， 完全閉塞に俩った胆道の再開通はみられなかった。
た症例 4 では約半年前の経皮経肝胆管造影 (PTC) に て胆石を認めなかったが，入院時には総胆管・胆言内 に多数の結石と胆管の圧排を認めた。

4) 膵管像：びまん性拡張 3 例, 中断 2 例が認められ た、膵管像と胆管像の変化には相関性を見出しえな かった。

5）門脈・脾静脈像：血管造影を行った 5 例中 3 例に 形態学的異常が認められた.すなわち脾静脈閉塞 3 例, 門脈狭窄 2 例である。しかしながら門脈圧亢進症を呈 した例はなかった（図 3）。

6) 胆汁細菌培昱：胆汁細菌検查を施行された 5 例 中 3 例 $(60 \%)$ でグラム陰性杆菌が検出された。

7) 胆囊組織像：5例で組織学的検索がなされたが, らち3 例で胆雯壁の肥厚, 炎症細胞浸潤などの慢性胆 囊炎の所見が見出された。

8）手術成績および転帰：術後合併症としては症例 1 で空腸・空腸吻合部狭窄による一過性イレウスを合 併したが，保存的療法にて治瘱した。そのほかの合併 症はなく, 術死, 晚期死も経験されず, 全例現在生存 中である。また術後黄㾝再発, 胆管炎症状るなく, 退 院した 5 例はすべて経過も良好で, 社会復帰している.

また術前に疼痛のみられた 4 例はすべて疼痛は消失 した.

\section{IV. 考察}

慢性荤炎に和ける胆管狭窄は以前より知られていた 
$か^{10)}$, 経皮経肝胆道造影 (PTC), 内視鏡的逆行性胆管 荤管造影 $(\mathrm{ERCP})$ などの直接胆道造影法が開発された

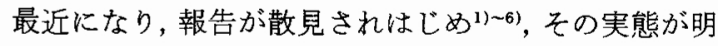
らかとなってきた。頻度は比較的高く, $3.2 \%$ $\left(\right.$ Yadegar $\left.^{31}\right), \quad 8 \%$ (Afroudakis $\left.{ }^{11)}\right), \quad 17 \%$ (Gradsinski ${ }^{12)}$ ), 32.1\% (佐藤 $\left.{ }^{4}\right)$ ), 46\% (Wisloff $\left.{ }^{6}\right)$ ) 報告されている．また脺炎患者では高ビリルビン血症 は868例中125例（14\%）でみられ，その原因としては 胆管狭窄が23\%で，その注かではアルコール性肝炎・ 肝硬変・薬剤性肝炎他の内科的原因 $31 \%$, 特発性 $46 \%$ との報告がある ${ }^{13)}$ ，慢性荤炎の患者ではフルコール常 飲者が大多数であるため, 黄疸が出現したとき，とく に無痛性の場合は, アルコール性肝炎・肝硬変による わのと容易に判断されやすいが，以上の報告の上うに 胆管狭窄をともなら例がかなり頻度で存在するといら 事を銘記しなければならない。この胆管狭窄は膵頭部 の線維化を主とする器質的変化と急性炎症増悪時の浮 腫性変化が主体であるが，その他膵頭部囊胞による圧 迫も一因之されている5 .

慢性脞炎にともなう胆管狭窄合併例では, 臨床症状 として, 荤炎の一般症状のほかに黄疸, 胆管炎症状を 合併することが特徵である ${ }^{1) ~}$ 。すなわち黄疸は $33 \sim 62 \%$ と高頻度に発現するが，一過性の事が多い之 されている2) 6). 自験例でも黄疸の既往のあった 4 例 中 2 例では，15日，30日で黄疸は消退した。しかしな がら, 胆管狭窄が悪化する例，胆道閉塞をきたす例む あり ${ }^{45)}$, 黄瘐の再発持続を示すことがある，自験例で る胆道造影を追跡した症例 1,2 では狭窄は改善され ず増悪していた。またほかの例でも慢性脺炎の急性増 悪後数力月経てから胆道造影がなされているが，やは り，総胆管の拡張と膵内胆管の狭窄が認められた。 た慢性荤炎に打ける膵の組織学的变化は元来非可逆性 であるので, 慢性荤资では黄疸が消失しても, 朠内胆 管が完全に正常に戻ることはなく,軽度の狭窄が続き， 慢性の胆汁らっ滞といら病態を呈することは容易に考 えられる。

次に胆管炎合併であるが，胆管狭窄を合併した慢性 腪炎例では, 胆管炎併発の頻度は，佐藤ら ${ }^{4)}$, Yadegar ら゙の報告では $4 \%, 14 \%$ と比較的頻度は低いが, Warshaw らの報告 ${ }^{14)}$ では50\%, Schulteらの報告2)では $38 \%$ と頻度が高い。度た胆汁中細菌培盖では $50 \%, 80 \%$ で細菌が検出されたという報告もある ${ }^{14) 15}$. 自験例で は発熱などの胆管炎の症状は 2 例にみられ, 胆汁中細 菌は 5 例中 3 例で検出され, 組織学的慢性胆囊炎は 5
例中 3 例で証明された。 また軟らかくるろい比較的新 しく形成されたも思われるビ系石が 3 例でみられたこ と（胆霊内 2 例，総胆管 1 例）は，胆管炎・胆汁 50 滞が存在することを示している，以上より本症例にお いては, 胆汁うっ滞, 胆管炎は高頻度で合併し, 本症 の病態を複雑悪化せしめる主因となっているものと考 えられた。

生化学的検査では, T. Bil の上昇は発黄時のみでそ の後下降するが, ALPの上昇が続くことが特徵で, 慢 性脞炎で ALP 上昇が 1 力月以上持続する例では, 胆 道系の精査を要するとされている(2) 6)(3) 16). 自験例で も ALP, $\gamma \mathrm{GTP}$ は $66 \%, 83 \%$ で持続的に高値をとって いた.

慢性膵炎に括ける胆道狭窄像の特徵は膵内胆管のほ 注全長にわたる，長い狭窄である。このため本症では 軽度の狭窄であっても，胆汁うっ滞，胆管炎などの合 併頻度が高いと推論される。自験例でも全例に肝側総 胆管の拡張がみられ，胆道内圧え進が示唆された。荤 内胆管像では, 佐藤らの分類 ${ }^{14)}$ に準ずると, 管状しめつ け像 2 例，不整狭窄像 2 例，圧排像 1 例，完全閉塞 圧排像 1 例が認められた。例数は少ないが荤石を有す るより進行した慢性茀炎例注ど, 壁不整像が多く認め られた。また当然のことながら，圧排像は脞頭部蕒胞 を有する例でみられた。これらの胆道像より良性・悪 性を診断するのはきわめて困難で，他の精査などより 総合的に判断せねばならない。

前述のごとく本症に和いては胆汁うっ滞, 胆管炎を 高頻度に合併するが，これにより上流の肝にかける負 担は大きく, 胆汁性肝硬変, 肝膿煌などへの進展する ことが少なくない(3)1114). Afroudakis ${ }^{11}$ は本症24例の 肝生検組織像を検討し, 胆汁 万っ滞79\%，二次性胆汁 性肝硬変 $29 \%$ 見出し, 肝生検を追跡した例では, 胆 汁性肝硬変が漸次増悪していることを証明した。また Warshaw $5^{(4)}$ / は本症 4 例の肝生検中, 胆汁性肝硬変 3 例 ( 5 ち門脈王穴進症合併 1 例), 慢性胆管炎 2 例, 胆汁らっ滞・肝膿瘍各 1 例を証明し, 適切な胆道バイ パス術後は肝機能, 肝組織とも正常に復したことを報 告している(14). 自験例では胆汁性肝硬变は経験されな かったが，胆管炎の持続する場合は肝生検などの検索 る必要と思われる。

次に慢性膵炎の治療であるが, 手術法としては腪に 対する直接手術の潘か, 間接手術として胆道系手術, 胃手術，内臟神経切除術などがある．疼痛に対しては 荤に対する直接手術が有効である ${ }^{16)}$ 。直接手術として 
は, 切除術717) と荤管减圧手術9)16)18)がある。びまん性慢 性萫炎の進行期でも，障害を受けた部の周囲に所々に 機能を有する荤組織が残存して打り ${ }^{19)}$ ，また切除によ り疼痛を消失させるためには広汎な苹切除を要し，尾 側荤切除の場合 $40 \sim 80 \%$ の切除が必要である反面, 広 汎な腪切除を行らほど糖尿病悪化, 下莉, 栄養不良, 晚期死亡がかなり頻度でみられるようになる ${ }^{16 / 18)}$. 一 方脞管减圧手術では鎮痛効果, 脞機能温存などいろい ろな点で切除術より優れていると報告されてい る16)18. したがってできる限り膵切除は避け, 膵管減圧 手術を採用する方針を採用してきた。朠管減圧術では, Puestow 手術と Partington 手術が Du Val 手術より 治療効果に打いて優れているとされている ${ }^{16) 201}$. 自験 例では初回手術ですあり, 癌が疑われた症例 5 以外で, 荤管の拡張をともなった 3 例に Partington の荤管・空 腸側々吻合を行い，頭部囊胞のみられた症例 4 では囊 胞・空腸吻合を行った。一方苹管の払張むなく, 疼痛・ 限局性荤病変をともなわなかった症例 6 には直接手術 は行わなかった。

次に胆管狭窄合併例での胆道付加手術につき検討す ると，方針として，胆道バイパスを要するという立 場2337)11114) と, 必ずしも必要としないとい5立場1446) と に分かれ，末だ統一した見解は得られていない。 Mewton ら'は術中に14F カテーテルが乳頭を通過す れば初回手術時には胆道バイパスをせず, 胆摘 $+\mathrm{T}$ チューブドレナージのみにとどめ, 術後経日的に狭窄 状態をみるという方針で行い，16例中14例は Tチ=ー ブをそのまま抜去しえたが，残りの 2 例では胆管狭窄 が改善されず，最終的には胆道バイパス術を要したと 報告した。しかしながら本症では前述のごとく, 胆汁 らっ滞・胆管炎が病態の中心にあり，これより胆汁性 肝硬変などへと進展することが少なからずあり, 胆管 狭窄は漸次進行することがあり, 現時点では将来の 朠・胆道病変の進行状況を予想しえないこと, 再手術 時の再建臓器・癒着の問題などより考えると，一期的 に胆道バイパフ術を行う方が，より安全と考えられる。 また慢性膵炎に扣ける痛みは，腪由来のるのだけでな く, 胆道由来のるのる含まれて㧍り，朠に対する手術 のみで軽快せず，同時に胆道系手術を要することがあ

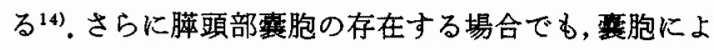
る圧迫以外に腪自体の変化による胆道狭窄が重要な要 素となっているため5), 震胞・空腸吻合のみでなく，胆 道バイパスを付加する必要がある。自験例では，すべ て胆道バイパスを付加するといら方針で, ALP る正常
化し, 胆汁らっ滞も解決したと思われ，良好な成績が 得られた。

胆道バイパス術式は良好な胆汁流出が得られ，上行 感染が少なく，生理的であるという事が最優先されね ばならない21)。胆裹を用いた胆道減圧術は効果が不十 分であり，乳頭形成も長い胆管狭窄には無効である 事 $^{24)}$ 上り，胆管・消化管吻合が適応となる。 また胆管・ 空腸吻合術後には胃液分泌が光進するため ${ }^{22)}$, 胆管・十 二指腸吻合がより生理的である。しかし，本症では荤 管ドレナージとあわせて行ら事が多いので, 再建術式 が問題となっている。自験例では胆道バイパス術 5 例 と胆管・十二指腸吻合が 2 例（空腸間置 1 例），胆管・ 空腸吻合が 3 例になされた。図 1 のごとく，再建は, 荤液と胆汁を別個のルートで消化管に流す double Roux-Y 法 2 例， ploop による一期的膵管・胆管・空腸 吻合を Roux-Y で再建する ploop, Roux-Y 法 1 例, 有 茎空腸間置法による胆管・十二指腸吻合 1 例を行った が，いずれの術式でも術後合併症, 胆管炎もなく, 良 好に経過した。これらの胆道・腪同時バイパス術には いまだ定まった方法はなく, 症例に応じ最適の方法を 選ぶべきであるが，できれば捇液と胆汁を別個のルー トで消化管へ流し，しかも生理的な十二指腸へ流入さ せ，上行性感染を併発し難い方法を工夫すべきである と考兄ている. 自験例の吻合・再建術式は以上の点を 必ずしも満していないが，現在まで良い結果を得てお ク，今後の症例にはさらに工夫を加えたい。

\section{結論}

胆管狭窄をともなった慢性腪炎手術例 6 例を検討し 以下の結論が得られた。

1）黄瘟は 4 例でみられ，5ち 3 例は自然消退した が，1例は胆管の完全閉鎖に対し PTCD を要した。

2）胆管炎・胆震炎 5 例, 胆汁 万っ滞・胆管炎に起因 すると思われる胆石 3 例, 胆汁細菌培養が $60 \%$ 陽性な どより，本症では胆道感染を高頻度に合併するものと 考えられた。

3）胆管像では全例で総胆管の拡張をともない,膵内 胆管ではしめつけ像 2 例, 不整狭窄像 2 例, 王排像 1 例, 完全閉塞像 1 例が認められた。 また壁不整像は脺 石合併例で強い傾向にあった。ささらに胆道造影像を追 跡した 2 例では, 胆管狭窄が 1 例で進行し, 完全閉塞 1 例では再開通を得なかった。

4）以上の症例に対し症例により double Roux-Y

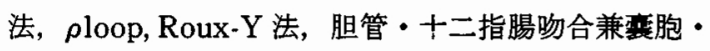
空腸吻合により 4 例に胆道・荤管同時バイバス術を 
行った注か，空腸間置法による胆管・十二指腸吻合，

脞頭十二指腸切除術を行い，良好な成績を得た。

本症では高頻度に胆汁うっ滞・胆道系炎症を合併す るため, 胆道バイパス術を膵に対する直接手術に付加 する必要があるすのと考觉られた。市た再建術式は症 例に応じた適切な術式を工夫すべさである。

$$
\text { 文献 }
$$

1) Newton BB, Rittenbury MS, Anderson MC: Extrahepatic biliary obstruction associated with Pancreatitis. Ann Surg $197: 645-652$, 1983

2) Schulte WJ, LaPorta AJ, Condon RE et al: Chrohic pancreatitis: A cause of biliary stricture. Surgery 197: 303-309, 1977

3) Yadegar J, Williams RA, Passaro E Jr et al : Commun duct stricture from chronic pancreatitis. Arch Surg $115: 582-586,1980$

4）佐藤寿雄, 宮下英二：慢性肝炎における胆管狭窄 とその対策. 胆と㬸 4:494-503，1983

5) Warshaw AL, Rattner DW: Facts and fallacies of common bile duct obstruction by pancreatic pseudocysts. Ann Surg $192: 33-37$, 1980

6) Wisloff F, Jacobsen J, Osens M : Stenosis of the common bile duct in chronic pancreatitis. Br J Surg 69:52-54, 1982

7) 羽生富士夫, 中村光司, 高田忠敬汪か：慢性荤炎の 外科的治療 (II)一治療成績ならびに予後。外科 $40 ： 939-947,1978$

8）慢性膵炎桧討委員会：慢性荤炎の臨床診断基準。 日消病会誌 $80: 1863-1866,1983$

9) Partington PF, Rochelle REL: Modified Puestow procedure for retrograde drainage of the pancreatic duct. Ann Surg 152: 1037-1043, 1960

10) Behrend M, Behrend A: Chronic pancreatitis causing complete and incomplete obstruction of the common bile duct. Arch. Surg $57: 51,1948$

11) Afroudakis A, Kaplowitz N : Liver histopath- ology in chronic common bile duct stenosis due to chronic alcoholic pancreatitis. Hepatology $1: 67-72,1981$

12) Grodsinski C: Surgical treatment of chronic pancreatitis. A review after a ten-year experience. Arch Surg 115: 545-551, 1980

13) Bradley III, Salam AA: Hyperbilirubinemia in inflammatory pancreatic disease: Natural history and management. Ann Surg 188: $626-629,1978$

14) Warshaw AL, Schapiro RH, Joseph $T$ et al: Persistent obstructive jaundice, cholangitis and biliary cirrhosis due to common bile duct stenosis in chronic pancreatitis. Gastroenterology $70: 562-567,1976$

15) Gregg JA, Cau-Lacke DL, Gallagher MM : Importance of common bile duct stricture associated with chronic pancreatitis. Diagnosis by endoscopic retrograde cholangiopancreatico. graphy. Am J Surg 141 : 199-203, 1981

16）佐藤寿雄, 宮川菊雄, 宮下英士ほか：慢性性膵炎の 手術適広子術式の選択. 消化器外科セミナー 5: 95-108, 1981

17) Frey CF, Child CG III, Frey W: Pancreatectomy for chronic pancreatitis. Ann Surg $184: 403-414,1976$

18) Proctor HJ, Mendes OC, Thomas CG Jr et al: Surgery for chronic pancreatitis: Drainage versus Resection. Ann Surg 189:664-672, 1971

19) Sarles H, Sahel J: Pathology of chronic calcifing pancreatitis. Am J Gastroenterol 66 : 117-139, 1976

20) Prinz RA, Greenlee HB: Pancreatic duct drainage in 100 patients with chronic pancreatitis. Ann Surg $194: 313-318,1981$

21) 木村 茂：胆道再建術：小児, 消化器外科七 ナー $11: 233-247,1983$

22）佐藤寿雄, 今村幹雄, 亀山仁一ほか：胆道再建術に おける問題点一Biliary diversion の胃酸分泌に及 ぼす影響についてー.外科 $43: 1035-1040,1981$ 